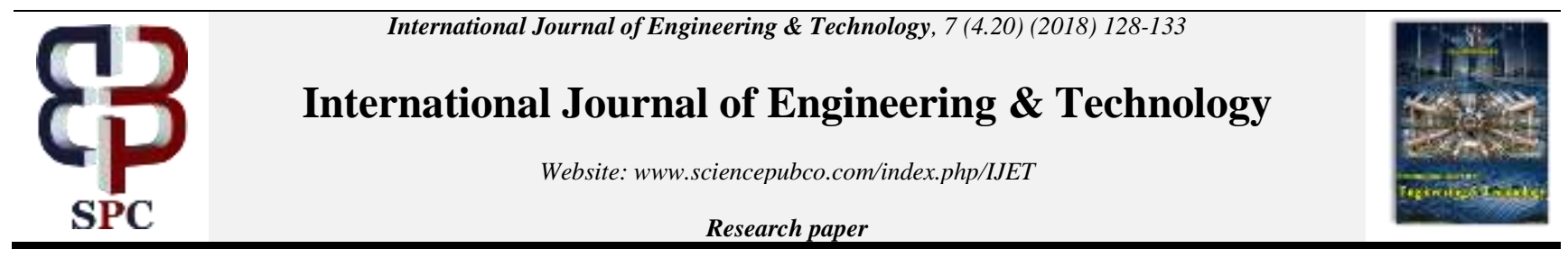

\title{
Salinity Management in the Shatt Al-Arab River
}

\author{
Khayyun Amtair Rahi \\ College of Engineering, Mustansiriyah University, Baghdad, Iraq \\ affiliated with Oklahoma State University, Oklahoma, USA \\ E-mail: khayyun.rahi@okstate.edu
}

\begin{abstract}
Shatt al-Arab River is originated at the confluence of Tigris and Euphrates in al-Qurna town in southern Iraq. Two other tributaries; the Karun and the Karkheh rivers; join the river downstream from the eastern bank. The length of Shatt al-Arab is about $192 \mathrm{~km}$ from its origin to its mouth in the Gulf. The width of the Shatt varies between $250 \mathrm{~m}$ at Qurna and $750 \mathrm{~m}$ at its mouth at Rass al-Bisha. The salinity of Shat al-Arab has increased steadily for the last four decades. High salinity of the shatt waters hindered their use and made them unfit for most domestic, agricultural and industrial uses. Salinity as high as $18500 \mathrm{ppm}$ was recorded in the City of Basra on the year 2009 . The prime cause of the salinity problem is the reduction of fresh water inflow from all the contributing rivers; the high salinity of the inflow from the Euphrates; the marshes; and Garmat Ali River. The research paper recommends an environmental (a minimum instream) flow of $145 \mathrm{cms}$ and several engineering works on the lower parts of the Euphrates and the Tigris rivers to assure the delivery of the proposed flow.
\end{abstract}

Keywords: Environmental flow, salinity of Shat al-Arab, City of Basra, the Iraqi marshes

\section{Introduction}

Water salinity generally measured as milligrams per liter $(\mathrm{mg} / \mathrm{l})$ or parts per million (ppm) of total dissolved solids (TDS). Other salinity measurements are $\mathrm{mg} / \mathrm{l}$ of chloride and electrical conductivity (EC) (Vengosh, 2004; NAS, 1993). Salinization of surface water results mainly from a combination of natural and anthropogenic causes. In the natural process, salts are deposited in the ground, near ground surface, and transported by groundwater to rivers and streams (Vengosh, 2004). In addition, salts concentration in rivers may increase by evaporation that occurs at large reservoirs behind dams, along the transmission channels, and at the smaller regulating reservoirs (Pillsbury, 1981).

Historically, Shatt al-Arab was of fresh water, except in the lower parts, where it was brackish (Buringh, 1960). The same author indicated that the river's waters were fresh until the town of Seeba where the fresh river water is mixed with salty seawater and salinity increased to about 2000 ppm. Harza (1963) stated "Developments on the Karun and Karkheh rivers in Iran may allow serious intrusion of sea water into the Shatt-el-Arab, with a consequent deterioration of its riparian date gardens, unless fairly substantial contributions are made from the Tigris and Euphrates. Shatt al-Arab salinity increased dramatically in the last four decades. Large rate of increases started in 1970s due to the construction of dams and reservoirs on the upstream of the Euphrates and Tigris Rivers (UN-ESCWA and BGR, 2013). The over regulation of the Euphrates and the Tigris led to a decrease in runoff and increase in salinity in Shatt al-Arab (Rahi and Halihan, 2010; UN-ESCWA and BGR, 2013). Water salinity measured by the National Center for Water Resources Management recorded levels of salinity much higher than the permissible limits (18500 ppm) in 2009 (CEB, 2011). The salinization problem is not limited to shatt al-Arab but affected, to lesser extent) the lower parts of the Euphrates and Tigris; south of Baghdad (Rahi and Halihan, 2010; Rahi and Halihan, 2018). This research is a comprehensive approach to investigate the Shatt al-Arab salinity problem, define the causes, and propose applicable engineering measures of remediation including a specified environmental flow.

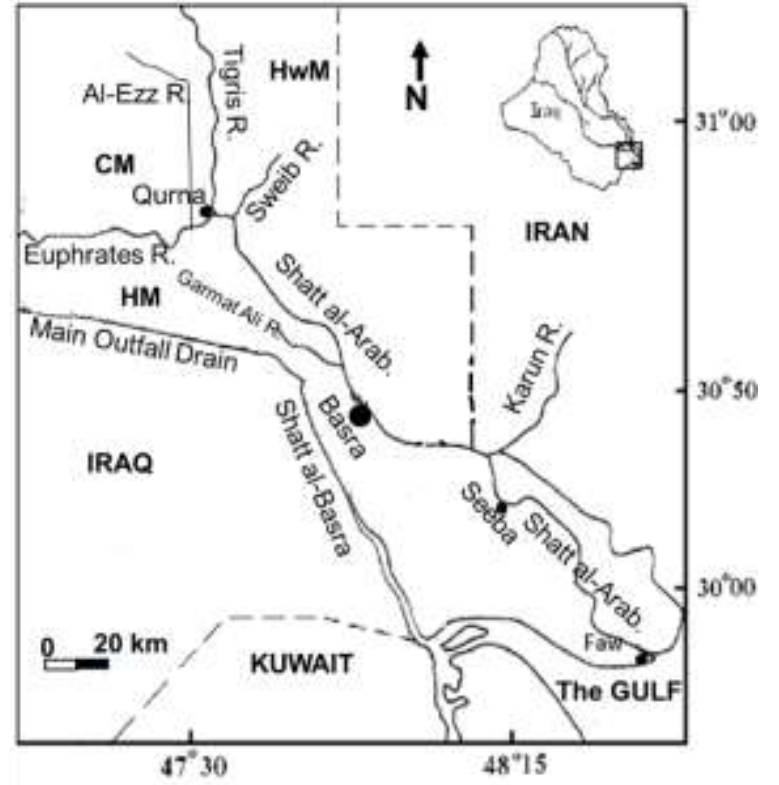

Fig. 1: Location map for Shatt al-Arab River and its tributaries. Not showing in the Figure is the Karkheh River, the forth tributary. But its flow enters the Shatt via Sweib River

\section{Hydrology of Shatt al-Arab River}

Shatt al-Arab River is originated at the confluence of Tigris and Euphrates in al-Qurna town in southern Iraq. It, then, flows in south-east direction toward the Persian (aka Arabian) Gulf (designated the Gulf hereafter) along the eastern part of the province of Basra. The Shatt drains the marshland of the lower Mesopotamia to 
the Gulf. The main marsh area is centered north and west of the origin point of Shatt al-Arab River. The area is divided into three major marshes: (i) al-Hammar Marshes (HM); (ii) the Central Marshes (CM) and (iii) al-Hawizeh Marshes (HwM) (Figure 1). Prior to the nineties of last century all of the three marshes drain into Shatt al-Arab. Al-Hawizeh was draining through al-Suwaib River. Al-Shafi River, which flows into Shatt al-Arab about $50 \mathrm{~km}$ south of the confluence (not shown in Figure, 1), was the outlet of the Central Marshes (after crossing the Euphrates River). Al-Hammar marsh join Shatt al-Arab via Garmat Ali River. Currently, alHammar Marsh is being recharged by saline water from the Main Outfall Drain of Iraq and possibly from the Gulf via Khor Abdallah during high tides (Polservice, 1980). Numerous streams branch out of Shatt al-Arab in the city of Basra and further downstream. The stream network of the Shatt is the basic irrigation and drainage system for the area (Polservice, 1980). Other surface water body that may serve as part of the hydrological system of Shatt al-Arab is Shatt al-Basra. Shat al-Basra is the hydraulic link between the Main Outfall Drain and the Gulf. It may contribute to the Shatt al-Arab via al-Hammar Marsh and Garmat Ali, especially during high tides. Recently, the government of Iraq constructed a 129-km irrigation canal with its intake just north of Basra and it ends at al-Faw city. The canal runs parallel to Shat al-Arab along the left bank, then it crosses the river at the Iraq-Iran border to run along the right bank. Total length of the river is about $192 \mathrm{~km}$, of which $95 \mathrm{~km}$ forms the border between Iran and Iraq (Partow, 2001; Abdullah, 2014). The Karkheh (via the Suwaib River) and the Karun (which is flowing southwest-ward from the Zagros Mountains of Iran) discharge into the left bank of the river (Partow, 2001). The former joins the Shatt $5 \mathrm{~km}$ downstream of al-Qurna, while the Karun flows into the Shatt about $40 \mathrm{~km}$ southeast of Basra and near the Iranian port city of Khorramshahr (Partow, 2001; Ghadiri and Ghadiri, 2004; Abdullah, 2014). The drainage basin of Shatt al-Arab River is defined in Figure (2). Garmat Ali River is joining Shat al-Arab in Basra. It serves as hydraulic connection between the Hammar marshes and Shat alArab.

Shatt al Arab width varies from 250-300 m near the city of Qurna to about $700 \mathrm{~m}$ near the city of Basra and more than $800 \mathrm{~m}$ near al Faw city, just north of its mouth at the Gulf (UN-ESCWA and BGR, 2013). The depth of the Shatt is about $(6-15 \mathrm{~m})$ and the bed slope is between 1 to $1.5 \mathrm{~cm} / \mathrm{km}$ (Polservice, 1980; Abdullah, 2014).

UN-ESCWA and BGR (2013) stated "the area draining to the Shatt al Arab covers about 145,190 km2, excluding the Euphrates and Tigris Basins (upstream of Qurna), but including the Karkheh and Karun sub-basins"; a conclusion this paper disagrees with. This paper considers the Shatt al-Arab River basin to include those of the Euphrates, the Tigris, the Karkheh, and the Karun rivers (Figure, 2). The total area of the Shatt al-Arab River basin is $806190 \mathrm{~km} 2$.

Shatt al-Arab, as estuary, is influenced by the tide phenomena of the Gulf. Two types of tides characterize the tidal phenomena of the Shatt; semi-diurnal and diurnal. Tides are important for agriculture because they irrigate and drain agricultural area adjacent to the river banks twice a day (Buringh, 1960; Polservice, 1980). The relationship between the tide magnitude and progression upstream through the Shatt to the Shatt inflow were studied by a Polish consultant firm during the late seventies. Results of their study confirms the inverse relationship between tides inland extension and its magnitude with the amount of discharges flowing into the Shatt (CEB, 2011; Polservice, 1980).

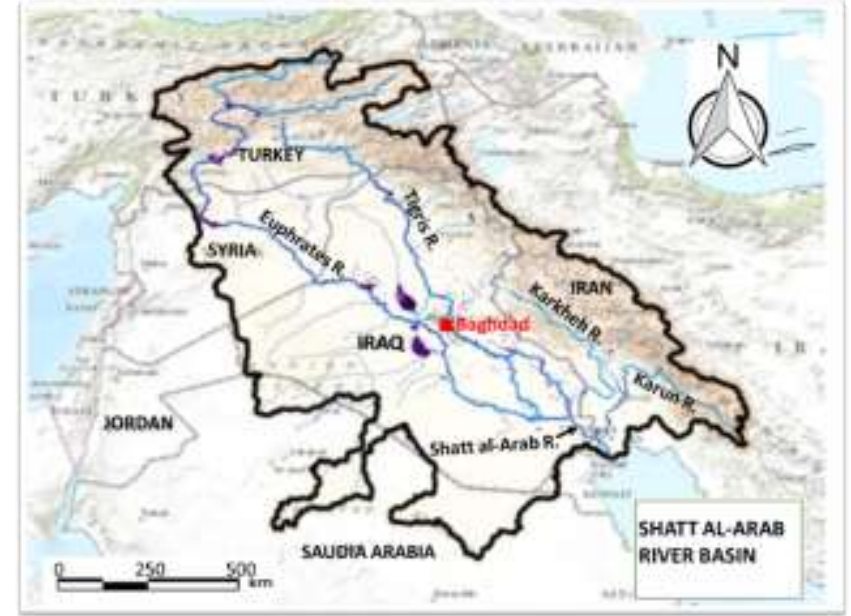

Fig. 2: Shatt al-Arab River Basin defined

\section{Methodology and data sources}

(TDS) and the associated discharge of Shatt al-Arab system in Iraq were analyzed to show the spatial changes with time. Analysis restricted to TDS because the problem in hand is high TDS on Shatt al-Arab that render its water useless. The source of the data will be mentioned when it was obtained if it is from published work, otherwise the source is the Iraqi Ministry of Water Resources (IMoWR). The discharge analysis is based on values measured by governmental agencies or modelled and estimated by previous researches (UN-ESCWA and BGR, 2013)

Salinity analyzed for five location. One location at each of the Euphrates River in Nasiriyah, the Tigris River in Amara, and Garmat Ali just north of Basra. The other two locations are in the confluence of the Tigris and Euphrates in al Qurna, and in Shat al-Arab at al-Basra city (designated as Ma'aqal). The discharge is available for fewer locations and analyzed accordingly.

\section{Salinity problem of Shatt al-Arab River}

Salinity increase in Shatt al-Arab may be attributed to salinity increase in the lower parts of Euphrates and Tigris rivers and decrease of fresh water inflow to the Shatt. In addition, high tides push salty seawater wedge from the Gulf to advance farther upstream. Research shows that inflow from the Tigris and Euphrates to the Shatt was about $665 \mathrm{cms}$ on 1972 (MoAR, 1972). In 1978 an annual flow of $910 \mathrm{cms}$ was published by (MoWR, 2014), als0, from the Tigris and the Euphrates. UN-ESCWA and BGR (2013) estimated the long-term annual inflow to the Shatt as $2340 \mathrm{cms}$. The flow rate is calculated as the sum of the long-term mean annual flow estimates of the four Shatt al Arab tributaries. A flow of $1450 \mathrm{cms}$ to the Shatt was reported by Isaev and Mikhailova (2009) based on the basinwide runoff estimate less evaporation losses prior to upstream regulatory structure.

Fresh water inflow to Shatt al-Arab from the Tigris and the Euphrates reduced to historical low levels (45 cms reported in 2011) due to dams and reservoirs constructed upstream (UN-ESCWA and BGR, 2013). Al-Mahmood (2015) reported average inflow to the Shatt of about $40 \mathrm{cms}$ from the Tigris River and about $12 \mathrm{cms}$ from the Euphrates River and no flow from the Iranian tributaries (Karun and Karkheh). This is a decrease of about 97 percent from the flow reported by UN-ESCWA and BGR (2013) and 90 percent reduction from the flow reported by MoAR (1972). Figure (3) prepared using Yaseen et. Al. (2014) inflow data from the Tigris and the Euphrates rivers. The figure shows the large reduction in the inflow of the more recent years compared to the inflow of 1977-1978. 


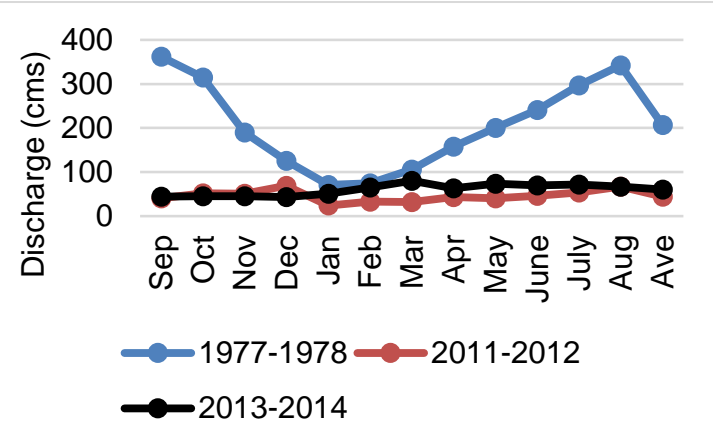

Fig. 3: Inflow from the Tigris and the Euphrates rivers to Shatt al-Arab river in three different water years. The pre-regulation flow is represented by the year 1977-1978.

Furthermore, the inflow from the Iranian Karun and Karkheh rivers is cut off completely due to the Iranian full control on the rivers via regulation and diversion hydraulic structures, the latest of which is the diversion of the Karun before its confluence with Shatt al-Arab River.

Saltwater intrusion to the shat is primarily driven by the tide phenomena. The tide wave advance in the water way is inversely related to the amounts of fresh water inflow from the rivers mentioned above. The lower the discharges the higher the tide wave and the more advances the tide wave makes toward the City of Qurna (the head point of Shatt al-Arab) (Polservice). Measurements and studies to the tide phenomenon and salinity variation along the course of the shatt are rare. Harza (1963) indicated that developments on the Karun and Karkheh rivers in

Iran may result in serious intrusion of sea water into the Shatt alArab. The National Center for Water Resources Management concluded that the quality of Shatt al-Arab water is influenced by the high salinity as well as oil spills from oil tankers (CEB, 2011). The center published salinity value of $18500 \mathrm{ppm}$ on the year 2009. Reported salinity value of the Shatt al Arab at Seehan (south of Basra) was $1,945 \mathrm{mg} / \mathrm{L}$ in 2010 and 2,408 $\mathrm{mg} / \mathrm{L}$ in 2011.

\section{Results}

\subsection{Salinity Analysis for the Shatt al-Arab System}

Temporal and spatial changes in salinity in the Shat a-Arab and the lower parts of the Tigris and Euphrates Rivers are investigated. Salinity data for 35 years and four measuring stations: the Euphrates at Nasiriyah; the Tigris at Amara; and Shatt al-Arab at Basra (Ma'aqal), plotted against time (year) in Figure (4). The Figure is meant to compare the Shatt al-Arab salinity with those of the main rivers that feed it.

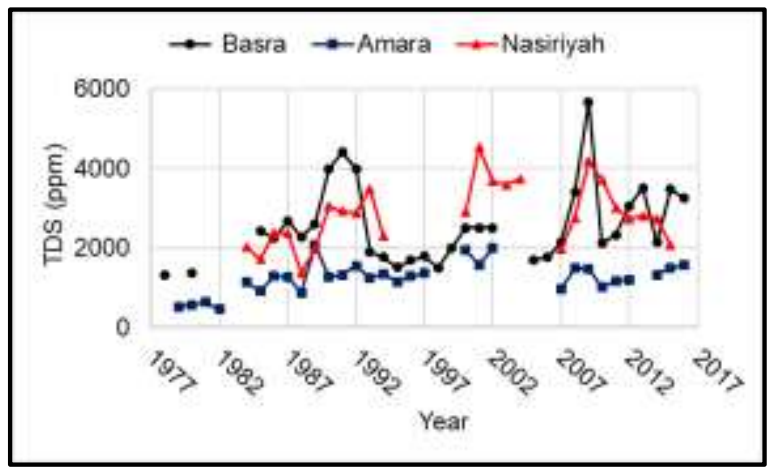

Fig. 4: Comparison of Shatt al-Arab salinity at Basra (Ma'aqal) to those of the Euphrates at Nasiriyah and the Tigris at Amara.

Salinity levels for all stations are higher than 1000 ppm starting from the year 1984 to present. The increase in salinity in the lower Tigris and Euphrates is attributed to the upstream control structures (Rahi and Halihan, 2010; Rahi and Halihan, 2018). Two periods of high salinity in the stations of Basra (Ma'aqal) and Nasiriyah: one was during the draining and drying of the marshes (1991-1993) when flow to the lower parts intentionally reduced; and the other one on 2009 when the flow of the Twin Rivers was historically low. In addition, Figure (4) shows that salinity levels remain high and have not decreased below 2000 ppm in the Euphrates at Nasiriyah and Shatt al-Arab in Basra.

\subsection{Salinity Analysis for Shatt al-Arab River in Basra}

The increase in salinity of the Shatt al-Arab may be traced back to the beginning of dam construction upstream the Euphrates River in the 70's of the last century when flow control structure introduced in the upstream of the Euphrates and the Tigris rivers. Available data show salinity in Basra (Ma'aqal Station) is high for the last 40 years, with an average of $2545 \mathrm{ppm}$. Water with such salinity is not suitable for drinking and most of other uses (Figure 5). Of special importance in Figure (5) is the pre-1987 period which represent the time before the full operation of Mosul Dam. The dam controls the flow on the upstream of the Tigris River. The salinity considered low relative to the rest of record, but still high and unfit for human consumption.

High salinity for this period most likely caused by the high evaporation rates of the marshes that drain into Shatt al-Arab.

Drying the marshes was a multi-dimension process started on 1991 and ended on the conclusion of 1993. During these seven years water supply to Shatt al-Arab were limited in quantity and low in quality. Therefore, the waters of the Shatt were of high salinity all year around. Post drying engineering works have had positive effects on water quality in Basra. In particular, the flow conveyed by a diked water course such as El-Ezz River lowered evaporation rates, hence lowered salt concentration; a process contributes to the relatively low salinity between 1993 and 1998 (Figure (5).

The last part of Figure (5) is the graph for the salinity of the years 2005-2016. In this interval, the Shatt receives no flow from the Euphrates, and receives less than $50 \mathrm{cms}$ from the Tigris. In recent years, most of the flow from the lower parts of the Twin Rivers was diverted to restore the Marshes. Salinity of the Shatt is higher than 2000 most of the time. The most important conclusion of Figure (5) is that salinity of Shatt al-Arab is above the standard limits for human consumption, and of limited use for agricultural and other applications.

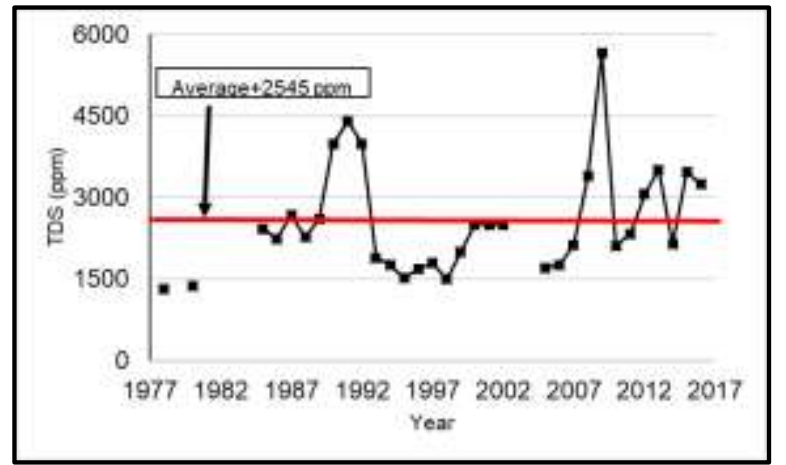

Fig. 5: Salinity in the city of Basra (Ma'aqal Station) for the last forty years. The average salinity is about 2545 ppm and the minimum is 1309 occurred on 1978.

\subsection{The impact of the Marshes of Southern Iraq on Shatt al-Arab River}

Historically, most of the Shatt al-Arab flow that comes from the Euphrates and Tigris passes through the vast marshes area then converges to the Shatt through multiple inlets. The spreading of water over large surface area with shallow depths and high evaporation rates constituted a major salinity sources to the waters of the Shatt. Following drying of the marshes, most of the inflows to Shatt alArab came from Tigris (relatively low salinity) directly and not 
through the marshland area. The effects of those flows are exhibited clearly on the years 1994-1997, which recorded relatively low salinity of Shat al-Arab in Qurna and Basra (Figure 6). A significant contribution of these inflows comes from a river (named al-Ezz) that was constructed as part of the marshes draining scheme. The river collects water from the ends of two branches originated on the right bank of the River Tigris just north of Amara City. Al-Ezz River flows eastward, then southward and ends into the Euphrates River $5 \mathrm{~km}$ upstream of Qurna (Figure 1). The relatively low-salinity waters of Al-Ezz have a positive influence on the saline waters of the Euphrates, which in turn reduce the Shatt al-Arab water salinity.

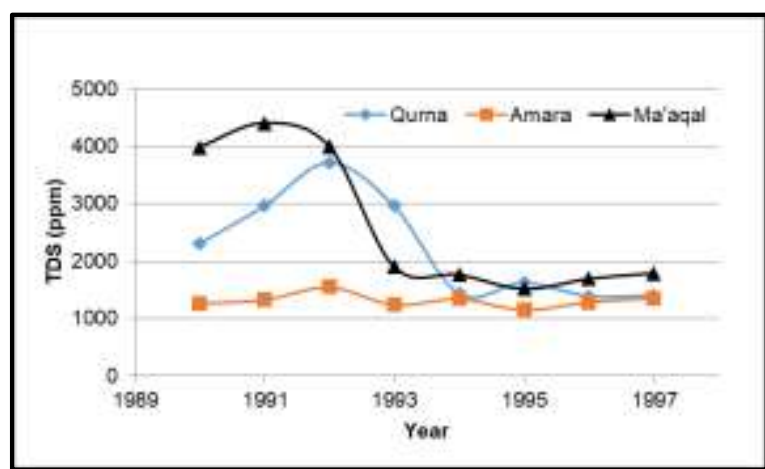

Fig. 6: The influence of al-Ezz River on the water salinity of Shatt al-Arab, especially in the confluence. Salinity decrease due to the fresh water contribution from the river.

\subsection{The impact of Garmat Ali River on the Salinity of Shatt al-Arab River}

A noticeable increase in salinity occurs in Shatt al-Arab downstream the inlet where Garmat Ali River joins the Shatt just north of Basra. Garmat Ali River drains the water of al-Hammar Marsh into Shatt al-Arab. A recent environment assessment of al-Hammar Marsh shows that the Marsh waters are saline with average TDS of $6840 \mathrm{ppm}$ for the year 2014 (Al-Gburi et. Al. 2017). Same authors indicate a possible mixing of the Hammar Marsh with Shatt alArab. More rigorous study was conducted by the Ministry of Water Resources (CEB, 2011) which include sampling from three points to assess the influence of Garmat Ali on Shatt al-Arab. CEB (2011) concluded that the Shatt salinity at al-Ma'aqal influenced by the salinity of Garmat Ali River. The results of their findings are summarized in Figure (7). The Figure shows an increase of salinity as high as $400 \mathrm{ppm}$ in Garmat Ali compared to Hartha (just upstream of the mouth of Garmat Ali). Al-Mahmoud, 2015 indicated that as much as 30 percent of Shat al-Arab salinity attributed to Garmat Ali. A report issued by MoWR (2014) have concluded that Garmat Ali contributes to the high salinity of Shatt al-Arab.

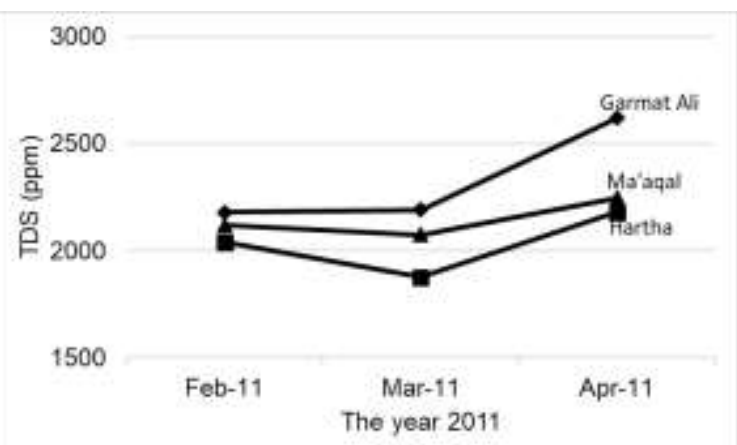

Fig. 7: The impact of Garmat Ali tributary on salinity of Shatt al-Arab in Basra (Ma'aqal Station). Salinity increase downstream of Garmat Ali confluence.

\subsection{Tides and Shatt al-Arab Salinity:}

Published research has not linked Shatt al-Arab salinity in the City of Basra with the advance of saline wedge nor that the sea water intrusion will impact Basra salinity. Polservice (1980) concluded that the saline wedge may advance $50 \mathrm{~km}$ inland from the mouth of the river or about $15 \mathrm{~km}$ upstream the City of Faw. In low discharge (less than $300 \mathrm{cms}$ in Basra) no sea wedge exist and stratification. But salinity increase in the lower parts of the river due to mixing between fresh water and sea water. CEB (2011) has confirmed the Polservice conclusions. MoWR (2014) went further to conclude that the saline sea water will not seriously impact the city of Basra even there is no fresh water discharge. This paper agrees with these conclusions. Furthermore, it seems that the fresh water discharge from the Karun River will constitute a decisive factor in preventing the saline water intrusion.

The results clearly linked the salinity problem to two main causes; the first one that is the most decisive is the flow reduction from the Euphrates, Tigris, the Karun rivers, and the second cause is the drainage from the marshes especially form al-Hammar marsh through Garmat Ali. One possible cause is the tidal influence from Shatt al-Basra. But the Shatt al-Basra influence need more studies to be confirmed.

\section{Salinity management options and recommen- dations}

Salinity control options are implemented in arid and semiarid areas in developed countries. The South Australia Murray River's managing authorities have initiated constructive and dynamic salinity control programs. The target is to maintain salinity at less than 800 microSiemens per centimeter $(\mu \mathrm{S} / \mathrm{cm})$ (about $512 \mathrm{ppm}$ TDS) at the city of Morgan for $95 \%$ of the time (BSM2030, 2015). The Morgan City is located at about 250 from the river mouth in the sea. The salinity target was achieved in 2010 through the combination of salt interception schemes, improved irrigation practices, and specific catchment programs (BSM2030, 2015).

In the United States, basin-wide salinity control and management programs have been applied to the Colorado River (USBR, 2013). The Colorado River salinity control measures include best management practices in irrigation practices, erosion control, reduction in natural saline water spring flows, and regulating salinity releases at large dams. A significant component of the Colorado River salinity control scheme is maintaining salt concentration of no greater than $115 \mathrm{ppm}(+/-30 \mathrm{ppm})$ above the average salinity at the Imperial Dam (USBR, 2013; Morford, 2014).

Salinity management options need to be directed toward lowering the salinity of Shatt al-Arab to less than $1000 \mathrm{ppm}$.

The management option considered for this paper is the environmental flow or the minimum instream flow. Environmental flow is the amount of assigned flow to minimize the negative consequences of reduced flow, caused by upstream structures, on the hydrological regime of the river in question to lessen the ecological impact of flow alteration (Poff and Matthews 2013). The Brisbane Declaration (2007) defines the environmental flow as the flow required to sustain freshwater and estuarine ecosystems along with other water consumers. The declaration went on to say that "water flowing to the sea is not wasted. Fresh water that flows into the ocean nourishes estuaries, which provide abundant food supplies, buffer infrastructure against storms and tidal surges, and dilute and evacuate pollutants."

The environmental flow, as a salinity management option, is recommended for Shatt al-Arab to control and remediate the salinity problem. Rahi and Halihan (2018) reviewed some approaches to determine the rate of the environmental flow applicable to Iraqi rivers. The environmental flow proposed by this paper for the Shatt alArab problem is $10 \%$ of the long-term mean annual flow from the four tributaries prior to regulations upstream. The pre-regulation flow from section 5 ranges from 1450 to $2340 \mathrm{cms}$. Accordingly, 
the proposed environmental flow from the four tributaries combine is between 145 to $234 \mathrm{cms}$. This flow must be maintained all times to suppress the high salinities of the Shat al-Arab River.

In addition, the following engineering measures are proposed to assure the delivery of the environmental flow and to separate the Shat al-Arab river from the marshes and to minimize pollution sources (Figure 8):

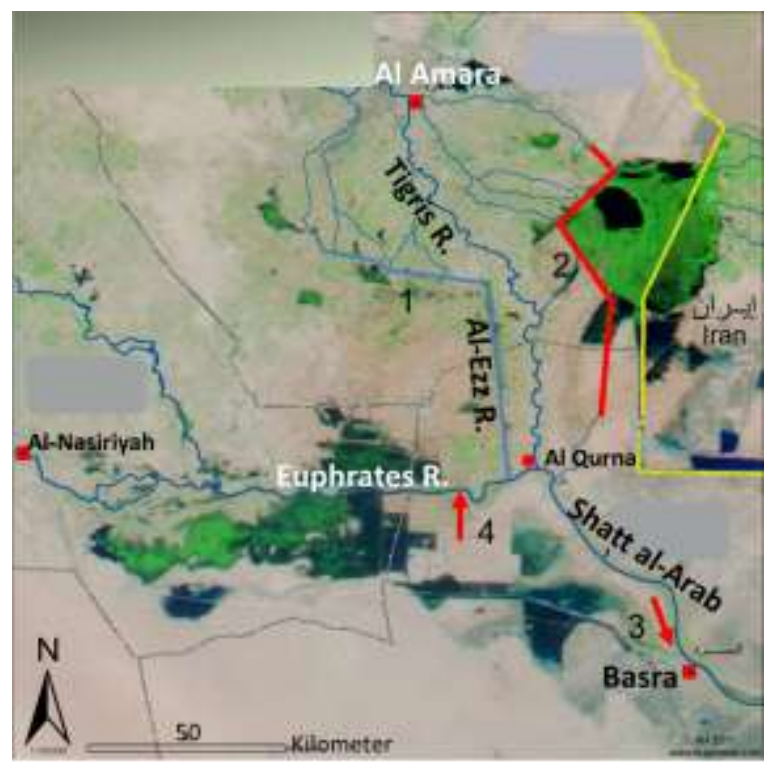

Fig. 8: Proposed engineering works in the lower Euphrates and Tigris as part of Shatt al-Arab remediation plan. The numbers designate the engineering modification as in section (6)

1. Reconstruct al-Ezz River: the positive impact of this river on salinity of the Shatt at al-Basra was discussed on section 6.3. The river was damaged intentionally or unintentionally after the year 2003. It proposed to restore the river based on its previous favorable environmental impact on the Shatt al-Arab River. The maximum discharge of the river is $600 \mathrm{cms}$.

2. Construct a confined water course in the left side of the Tigris River, like al-Ezz River, to collect the flow from the lower ends of al-Msharah and al-Alekhala Rivers and run parallel to the Iraq-Iran border line. It, then, flows into the existing al Suwaib River which flows into Shatt al-Arab. The estimated discharge of this watercourse is $100 \mathrm{cms}$. This step will enhance the fresh water supplies to Shatt al-Arab.

3. Extend one distributary of the Euphrates from the City of Suq Alshiukh (West of Nasiriyah) to join Shat al-Arab through Garmat Ali. The Euphrates River branches into five branches near Suq Alshiukh. These branches die in the marshes or rejoin the main river course after some distance. This step of the remediation proposal is intended to connect one of the Euphrates branches directly to Shatt al-Arab via Garmat Ali. Two goals will be achieved by this step: isolate Garmat Ali from al-Hammar Marsh and Shatt al-Basra and enhance the Shatt with the Euphrates water which is of lower salinity compared to the water of al-Basra. The estimated discharge is about $300 \mathrm{cms}$ which makes this canal function as a replacement of the demolished Mother of Battles River.

4. Remove the earth dam on the Euphrates and allow the river to flow to Shat al-Arab confluence at al-Qurna. This earthen dam was constructed on the Euphrates at a point just upstream of alMidaina town (please see Figure 8). Removing this dam will restore the historical hydrological and hydraulic connection between the Euphrates and Shatt al-Arab and enhance fresh water supplies to the Shatt.

5. Stop all agricultural return flow (agricultural drainage water) to the Tigris and the Euphrates. Rahi and Halihan (2010 and 2018) have recommended a similar step and presented details about names and location of drains need to be diverted away from the
Euphrates and Tigris to decrease the salinity in the lower parts of the Twin Rivers.

\section{Conclusion}

Shatt al-Arab is classified as a river with four tributaries: The Euphrates, the Tigris, and the Iranian Karkheh and Karun rivers. Furthermore, and throughout of its history, Shatt al-Arab is fresh water river. The recent increase in salinity is attributed to a sharp decrease in inflows from some tributaries and a complete cut off fresh water supplies from others and to marshes drainage water. The paper concludes that the needed salinity option to control the salinity problem of the river is constant supplies of at least $145 \mathrm{cms}$ of fresh water as an environmental flow. In addition, several hydraulic structures need to be constructed, modified, or removed in the lower parts of the Euphrates and Tigris to insure the continues supplies of the proposed environmental flow and to separate Shat al-Arab from the marshes.

\section{Acknowledgement}

This research was sponsored by the University of Mustansiriyah. For that, thanks are due the University and the College of Engineering.

\section{References}

[1] Abdullah S S (2014) Tide phenomena in the Shatt Al-Arab River, South of Iraq, Journal of the Arabian Gulf, 42(3\&4), 133-155

[2] Alfartusi A J, Al-Hashimi N H N and Al-Taie S A (2013) Hydrodynamic simulation model of the Shatt Al-Arab River, International Journal of Emerging Technologies in Computational and Applied Sciences, 4(3), 289

[3] Al-Gburi, H.; Al-Tawash, B. and Al-Lafta, H., (2017), Environmental Assessment of Al-Hammar Marsh, Southern Iraq. Heliyon, 3: 1-26, doi.org/10.1016/j.heliyon.2017.e00256

[4] Al-Mahmood H K (2015) Hydrological changes in the lower part of Mesopotamian Basin, Iraq, Journal of Aquacult. 12(1), 47-70

[5] Basin Salinity Management 2030 (BSM2030), (2015), Published by the Murray-Darling Basin Ministerial Council.

[6] Buringh P (1960) Soils and Soils Conditions in Iraq, Directorate of General Agricultural Research and Projects, The Ministry of Agriculture, Baghdad

[7] CEB (Consultant Engineering Bureau) (2011) Shatt Al-Arab, final report (in Arabic), College of Engineering, University of Baghdad, 101, (Unpublished).

[8] Ghadiri H and Ghadiri M (2006) Marshlands of Mesopotamia and the Rivers that Feed Them, The 8th International River Symposium, September 4-7, Brisbane, Australia, 1-15. http://archive.riversymposium.com/2004/index.php?element $=21$

[9] Harza Engineering Company (1963) Hydrologic survey of Iraq: final report, Baghdad

[10] Isaev, V.A. \& Mikhailova, M.V. (2009), The Hydrography, Evolution, and Hydrological Regime of the Mouth Area of the Shatt AlArab River, Water Resour, 36: 380. https://doi.org/10.1134/S0097807809040022

[11] Marin Science Center, (1991), Shatt al Arab elementary Scientific Studies, Al Basra University, Ministry of higher education and scientific research. (Unpublished) cited by Dinar, a. A., (2016), Modelling Approaches to Understand Salinity Variations in highly dynamic tidal river: the case of the Shatt al-Arab River, Doctor Dissertation, Delft University of Technology and of the Academic Board of the UNESCO-IHE, the Netherlands

[12] Morford, S., Salinity in the Colorado River Basin, 2014 (available at: https://watershed.ucdavis.edu/education/classes/files/content/page/6\%20Morford-Colorado Basin_Salinity.pdf.)

[13] National Academy of Sciences (NAS) (1993), Committee on Agriculture, Soil and Water Quality, An Agenda for Agriculture, National Academy Press, Washington, DC, 516.

[14] MoAR (Ministry of Agrarian Reforms) (1972), Study report on the Shatt Al-Arab project, Iraq, prepared by Nippon Koei Co. LTD., Japan, Unpublished report 
[15] MoWR (Ministry of Water Resources), (2014), Shatt al-Arab Irrigation project: Technical Report, Vol VIII, Studies on Salinity Problems, Iraq, Unpublished report.

[16] Partow H (2001) the Mesopotamian Marshlands: Demise of an Ecosystem Early Warning and Assessment Technical Report, UNEP/DEWA/Tr 01-3 Rev. 1, Division of Early Warning and Assessment. United Nations Environment Program, Nairobi, Kenya.

[17] Pillsbury A F (1981) The Salinity of Rivers, Scientific American, 245(1), 54-65.

[18] Poff NL and Matthews JH (2013) Environmental flows in the Anthropocence: past progress and future prospects. Current Opinion in Environmental Sustainability 5(6): 667-675

[19] Polservice (1980) Shatt Al-Arab Project-Feasibility Report, VII, Ministry of Irrigation, Iraq.

[20] Rahi K A and Halihan T (2010) Changes in The Salinity of The Euphrates River system in Iraq, Regional environmental change, 10(1), 27-35

[21] Rahi, K.A. \& Halihan, T. Reg Environ Change (2018), Salinity Evolution of the Tigris River, https://doi.org/10.1007/s10113-018-13444

[22] The Brisbane Declaration (2007). "Environmental flows are essential for freshwater ecosystem health and human well-being," in 10th International River Symposium and International Environmental Flows Conference (Brisbane, QLD). Available online at: https://www.conservationgateway.org/ConservationPractices/Freshwater/EnvironmentalFlows/MethodsandTools/ELOHA/Pages/Brisbane-Declaration.aspx

[23] UN-ESCWA and BGR (United Nations Economics and Social Commission for Western Asia; Bundesanstalt für Geowissenschaften und Rohstoffe) (2013) "Chapter 3, Tigris River Basin" Inventory of Shared Water Resources in Western Asia, Beirut.

[24] USBR (United States Bureau of Reclamation) (2013), Quality of water, Colorado River Basin, Progress Report No. 24, Reclamation: Managing Rivers in the West.

[25] Vengosh, A., (2004), Stalinization and Saline Environment, Treatise on Geochemistry, 9. Amsterdam: Elsevier, pp 333-365.

[26] Yaseen, B. R., Al-Asaady, K. A., Kazem, A. A., Chaichan, M. T. (2014), Environmental impacts of salt tide in Shatt al-ArabBasra/Iraq, IOSR, Journal of Environmental Science, Toxicology and Food Technology, vol. 10, No. 1-2, pp. 35-43, 2016 (DOI :10.9790/2402-10123543) 